\title{
Prediction of Gas Holdup in a Three-Phase Internal Loop Airlift Fluidized Bed Reactor Using Newtonian and non-Newtonian Liquids
}

\author{
Sivakumar Venkatachalam (Corresponding author) \\ Department of Food Technology, Kongu Engineering College, Perundurai-638 052, Tamilnadu, India \\ Tel: 91-04294-226-606 Fax: 91-04294-220-087 E-mail: drvsivakumar@yahoo.com
}

Akilamudhan Palaniappan

Department of Chemical Engineering, Erode Sengunthar Engineering College

Perundurai-638 057, Tamilnadu, India

Tel: 91-04294-232-701, Fax: 91-04294-232-705Ｅ-mail: akilamudhan@yahoo.co.in

Kannan Kandasamy

Department of Chemical Engineering, Kongu Engineering College

Perundurai-638 052, Tamilnadu, India

Tel: 91-04294-226-602, Fax: 91-04294-220-087Ｅ-mail: kannank@kongu.ac.in

\begin{abstract}
The effect of superficial gas and liquid velocities, particle diameter and sphericity, physical and rheological properties of liquids on gas holdup were studied in a three phase internal loop airlift fluidized bed reactor. Air was used as a gas phase. Water, n-butanol, various concentrations of glycerol (60\% and $80 \%)$ were used as Newtonian liquids and different concentrations $(0.25 \%, 0.6 \%$ and $1.0 \%)$ of carboxy methyl cellulose (CMC) solutions were used as non-Newtonian liquids. Spheres, Bearl saddle and Raschig ring with different diameters were used as solid phases. Superficial gas velocity varied from $0.000142 \mathrm{~m} / \mathrm{s}$ to $0.005662 \mathrm{~m} / \mathrm{s}$ and superficial liquid velocity varied from 0.001 to $0.12 \mathrm{~m} / \mathrm{s}$. The experimental result shows that increase in particle size and superficial gas velocity increases gas holdup and decreases with increase in concentration of Newtonian and non-Newtonian systems. Based on the experimental results a separate correlation was developed to predict gas holdup for both Newtonian and non-Newtonian liquids for wide range of operating conditions.
\end{abstract}

Keywords: Internal loop airlift reactor, Gas holdup, Newtonian, Non - Newtonian

\section{Introduction}

Internal loop airlift fluidized bed reactors are widely used in chemical and petrochemical industries for their advantages like high efficiency of homogeneities and intense mixing in the absence of moving parts. In biochemical industries these reactors are used for high oxygen transfer rate, minimum cell rupture compared to external driven mixing system such as agitated vessels. In order to design, scale-up and for flexible operation of three-phase internal loop air-lift fluidized bed reactors for continuous effluent treatment process or biochemical applications, knowledge of the hydrodynamic parameter gas holdup is essential. Internal loop airlift fluidized bed reactor is constructed by mounting a draft tube inside a bubble column, the column is divided into two zones; one is gas sparged riser, an unsparged down comer, and a degassing zone at the top to remove the gas bubble from the riser. The compressed gas is sparged into the riser zone. The gas hold up in riser creates a density difference between the riser and down comer which induces liquid circulation. This liquid circulation enhances heat and mass transfer between phases are totally depends on the gas hold up, which is major hydrodynamic parameter for scale up. Many authors experimentally studied the gas holdup in three phase internal loop airlift fluidized bed reactors (Koide et al.1983 \&1984, Freitas et al.1999, Lo et al.2003, Garcia-Calvo et al.1999, Sun et al.2005 \& 2006, Tobajas et al.1999, Olivieri et al.2003, Zhang et al.2005) with Newtonian liquid systems. Only few authors dealt with non-Newtonian liquids in three phase internal loop airlift fluidized bed reactor (Kennard and Janekeh 1991, Li et al.1995, Hwang et al.1997, Jin et al.2006) but they restricted their studies only with stagnant liquid systems. Since effluent treatment is a continuous process and nature of effluent may behave either Newtonian or non-Newtonian depending on the source and concentration of pollutants, there is need to study the influence of fundamental and operating variable on the above said parameters and hence in this paper 
an attempt has been made to study the influence of particle diameter, sphericity, superficial gas and liquid velocities, physical and rheological properties of Newtonian and non-Newtonian liquids on gas holdup and to develop a correlation to determine the gas holdup from the fundamental and operating variable.

\section{Experimental set up and Procedure}

The schematic diagram of the experimental setup is shown in Fig. 1.The reactor was constructed of $0.15 \mathrm{~m}$ id Perspex column and $1.63 \mathrm{~m}$ in height. Inside diameter of the draft tube was 0.084 and $1.54 \mathrm{~m}$ in height. The draft tube was located above $0.09 \mathrm{~m}$ from the gas distributor. Air was sparged into the draft tube through sparger which is $0.08 \mathrm{~m}$ in diameter with holes of $0.0008 \mathrm{~m}$ each located slightly below the perforated plate. Gas holdup was measured by volume expansion method (Chisti, 1989). The densities of the liquids were measured by specific gravity method and the rheological properties of non-Newtonian liquids were measured by using Brookfiled Rheometer. Superficial gas velocities are varied from $0.000142-0.005662 \mathrm{~m} / \mathrm{s}$. Superficial liquid velocities are varied from 0.001 to $0.12 \mathrm{~m} / \mathrm{s}$. The liquids used in this study were tap water, n-butanol and $60 \%$ and $80 \%$ concentrations of glycerol were used as Newtonian fluids and various concentrations of $(0.25 \%, 0.6 \%$ and $1.0 \%) \mathrm{CMC}$ was used as non-Newtonian fluids. Different diameters of Spheres, Bearl saddle and Raschig ring were used as solid phases. Experiments have been carried out in an atmospheric temperature with oil free compressed air as gas phase. The properties of liquids and solid particles used in the present study are given in Tables 1 and 2.

\section{Results and Discussions}

\subsection{Effect of phase flow rates on gas holdup}

Effect of superficial gas and liquid velocity on gas holdup for air-water system is shown in the Fig. 2. From the Fig. 2 it is observed that an increase in superficial liquid velocity increases the velocity of the gas bubble and hence gas holdup decreases. Increase in superficial gas velocity increases the fraction of gas bubbles in the column resulting increase in gas holdup. Similar results were also obtained by Koide et al. (1983) for air-water system. The same trend was also observed for different particle sizes in air-butanol, air- $80 \%$ glycerol, and air-0.6\% CMC system which are shown in Figs. 3- 6.

\subsection{Effect of particle diameter and sphericity on gas holdup}

Effect of particle diameter on gas holdup for air-water system is shown in Fig. 7 which is drawn between superficial liquid velocity and gas holdup. From the Fig. 7 it is observed that an increase in particle diameter increases gas holdup. Figs. 8-11 show the effect of sphericity of particles on gas holdup for different superficial gas velocities. From the Figs it is observed that increase in particle sphericity does not have any significant influence on gas holdup.

\subsection{Effect of physical properties of liquids on gas holdup}

Figs. $12 \& 13$ show the effect of physical properties of air-water, air-butanol, air- $60 \%$ glycerol and air- $80 \%$ glycerol systems on gas holdup for the superficial gas velocities $0.001415 \mathrm{~m} / \mathrm{s}$ and $0.005662 \mathrm{~m} / \mathrm{s}$ respectively. The Figs. $12 \& 13$ show that an increase in concentration of liquid decreases the gas holdup; this may be due to the formation of large bubbles at higher concentrations of solutions. The same trend was also observed by Hwang et al. (1997) and Wen et al. (2005). From these Figs it is also observed that decreasing surface tension of liquid increases gas holdup. Fig. 14 shows the effect of fluid behavior index for $0.25,0.6$ and $1.0 \%$ CMC liquids. From the Fig. 14 it is observed that an increase in fluid behavior index of liquid decreases the gas holdup. The same trend was also observed for the superficial gas velocity $0.005662 \mathrm{~m} / \mathrm{s}$ which is shown in Fig. 15 .

From the analysis of literature it is found that none of the authors developed correlation to predict gas holdup for wide range of operating variables using Newtonian and non-Newtonian liquids. From the experimental data, a separate dimensionless correlation was developed to predict the gas holdup, which can be used for Newtonian and non-Newtonian liquids for continuous flow.

$\varepsilon_{g}=0.98\left(F_{r g}\right)^{0.1}\left(F_{r l}\right)^{-0.036}\left(\frac{d_{p}}{d_{c}}\right)^{0.8}\left(\frac{\rho_{P}-\rho_{L}}{\rho_{L}}\right)^{-0.55}\left(M_{O}\right)^{-0.04}$---- Eq. 1

The comparisons of our experimental and calculated values of the gas holdup for Newtonian and non-Newtonian liquids are shown in Figs. 16 and 17. They show good agreement between the experimental and calculated gas holdup with the average deviation of $15 \%$ for 1580 data. 


\section{Conclusion}

The experimental results show that the increase in particle diameter increases the gas holdup and decreases with increase in superficial gas velocity for air-water, air-butanol, air- $80 \%$ glycerol and air- $0.6 \%$ CMC systems with different particle sizes. The increase in concentration and fluid behaviour index of liquids decreases gas holdup.

\section{Nomenclature}

$d_{p}$ - Diameter of the particle, $m$

$\mathrm{d}_{\mathrm{c}}$ - Diameter of the column, $\mathrm{m}$

$\mathrm{Fr}_{\mathrm{g}}$ - Froude number for gas- $F r_{g}=\frac{U_{g}{ }^{2}}{g \cdot d_{p}}$

$\mathrm{Fr}_{1}$ - Froude number for liquid- $F r_{l}=\frac{U_{l}^{2}}{g \cdot d_{p}}$

$\mathrm{g}$ - Acceleration due to gravity, $\mathrm{m} / \mathrm{s}^{2}$

$\mathrm{K}$ - Fluid behavior index

$\mathrm{M}_{0}$-Morton number-Mo $=\frac{\left[K\left(\frac{U_{l}}{d_{p}}\right)^{n-1}\right]^{4}}{\rho_{l} \sigma_{l}^{3}} g$

n- Fluid consistency index

$\mathrm{U}_{\mathrm{g}}$ - Superficial gas velocity, $\mathrm{m} / \mathrm{s}$

$\mathrm{U}_{\mathrm{l}}$ - Superficial liquid velocity, $\mathrm{m} / \mathrm{s}$

$\rho_{\mathrm{s}}$ - Density of the solid, $\mathrm{kg} / \mathrm{m}^{3}$

$\rho_{\mathrm{l}}$ - Density of the liquid, $\mathrm{kg} / \mathrm{m}^{3}$

$\varepsilon_{\mathrm{g}}$ - Gas holdup

$\sigma_{1}-$ Surface tension of liquid, N/m

\section{References}

Blazej, M., Kisa, M., \& Markos, J. (2004). Scale influence on the hydrodynamics of an internal loop airlift reactor. Chemical Engineering and Processing, 43, 1519-1527

Calvo, E. G. (1989). A Fluid dynamic model for airlift loop reactors. Chemical Engineering Science, Vol.44, No.2, pp 321-323

Chisti, M. Y., Halard, B., \& Moo-Young, M. (1988). Liquid circulation in airlift reactors. Chemical Engineering Science, Vol.43, No.3, pp 451-457

Chisti, M. Y. (1989). Airlift Bioreactors, Elsevier, London.

Chisti, Y., Wenge, F., \& Moo-Young, M. (1995). Relationship between riser and down comer gas holdup in internal-loop airlift reactors without gas-liquid separators. The Chemical Engineering Journal, 57, B7-B13

Fadavi, A., \& Chisti, Y. (2007). Gas holdup and mixing characteristics of a novel forced circulation loop reactor. Chemical Engineering Journal, 131, 105-111

Freitas, C., Fialova, M., Zahradnik, J., \& Teixeira, A. J. (1999). Hydrodynamic model for three phase internal and external loop airlift reactors. Chemical Engineering Science, 54, 5253-5258

Garcia-Calvo, E., Rodriguez, A., Prados, A., \& Klein, J. (1999). A Fluid dynamic model for three phase airlift reactors. Chemical Engineering Science, 54, 2359-2370

Gouveia, E. R., Hokka, C. O., \& Badino-Jr, A. C. (2003). The effects of geometry and operational conditions on gas holdup, liquid circulation and mass transfer in an airlift reactor. Brazilian Journal of Chemical Engineering, Vol. 20, No. 4

Hwang, S. J., \& Cheng, Y. L. (1997). Gas holdup and liquid velocity in three phase internal loop airlift reactors. Chemical Engineering Science, 52, No 21, 22, pp 3949-3960 
Hwang, S. J., \& Lu, W. J. (1997). Gas-Liquid mass transfer in an internal loop airlift reactor with low density particles. Chemical Engineering Science, 52 Vol. 52, No. 5, pp 853-857

Jin, B., Yin, P., \& Lant, P. (2006). Hydrodynamics and mass transfer co-efficient in three phase airlift reactors containing activated sludge. Chemical Engineering and Processing, 45, 608-617

Koide, K., Sato, H., \& Iwamoto, S. (1983). Gas hold up and volumetric liquid-phase mass transfer coefficient in bubble column with draught tube and with gas dispersion into annulus. Journal of Chemical Engineering of Japan, Vol. 16, No. 5, 1983

Koide, K., Horibe, K., Kawabata, H., \& Ito, S. (1985). Gas holdup and Volumetric Liquid-Phase mass transfer coefficient in solid-suspended bubble column with draught tube. Journal of Chemical Engineering of Japan, Vol. 18, No. 3, 1985

Korpijarvi, J., Oinas, P., \& Reunanen, J. (1999). Hydrodynamics and mass transfer in an airlift reactor. Chemical Engineering Science, 54, 2255-2262

Livinston, A. G., \& Zhang, S. F. (1993). Hydrodynamic behaviour of three-phase (Gas-Liquid-Solid) airlift reactors, Chemical Engineering Science, Vol.48, No.9, pp 1641-1654

Lo, C. S., \& Hwang, S. J. (2003). Local hydrodynamic properties of gas phase in an internal loop airlift reactor. Chemical Engineering Journal, 91, 3-22

Lu, W. J., Hwang, S. J \& Chang, C. M. (1995). Liquid velocity and gas holdup in three-phase internal loop airlift reactors with low-density particles. Chemical Engineering Science, Vol. 50, No. 8, pp 1301-1310

Olivieri, G., Marzocchella, A., \& Salatino, P. (2003). Hydrodynamics and mass transfer in a lab scale three-phase internal loop airlift. Chemical Engineering Journal, 96, 45-54

Siegel, M. H., \& Robinson, C. W. (1992). Applications of airlift gas-liquid-solid reactors in biotechnology. Chemical Engineering Science, Vol.47, No.13/14, 3215-3229

Shamlou, P. A., Pollard, D. J., Ison, A. P., \& Lilly, M. D. (1994). Gas holdup and liquid circulation rate in concentric tube airlift bioreactors. Chemical Engineering Science, Vol, 49, No.3, pp 303-312

Sun, S., Liu, C., Wei, W., \& Bao, X. (2006). Hydrodynamics of an airlift reactor. Powder Technology, 162, 201-207

Sun, S., Bao, X., Liu, C., Xu, J., \& Wei, W. (2005). Hydrodynamic model for three phase annulus airlift reactors. Ind.Eng.Chem.Res., 44, 7550-7558

Talvy, S., Cockx, A., \& Line, A. (2005). Global modelling of a gas-liquid-solid airlift reactor, Chemical Engineering Science, 60, 5991-6003

Tobajas, M., Garcia-Calvo, E., Seigel, M. H., \& Apitz, S. E. (1999). Hydrodynamics and mass transfer prediction in a three-phase airlift reactor for marine sediment biotreatment" Chemical Engineering Science, 54, 5347-5354

Wen, J., Jia, X., Cheng, X., \& Yang, P. (2005). Characteristics of three phase internal loop airlift bioreactors with complete gas recirculation for non-Newtonian fluids. Bio process, Bio Syst Engg, 27:193-205

Yu, W., Wang, T., Song, F., \& Wang, Z. (2009). Investigation of the gas layer height in a multistage Internal loop airlift reactor. Ind.Eng.Chem.Res., 48, 9278-9285.

Zhang. T., Wang, J., Luo, Z., \& Jin, Y. (2005). Multiphase flow characteristics of a novel internal-loop airlift reactor. Chemical Engineering Journal, 109, 115-122. 
Table 1. Properties of liquids

\begin{tabular}{|l|l|l|l|l|}
\hline \multicolumn{1}{|c|}{$\begin{array}{c}\text { System } \\
\text { description }\end{array}$} & \multirow{2}{*}{$\begin{array}{c}\text { Liquid density } \\
\left(\rho_{1}\right) \mathrm{kg} / \mathrm{m} 3\end{array}$} & \multicolumn{1}{|c|}{$\begin{array}{c}\text { Surface tension } \\
\left(\sigma_{\mathrm{l}}\right) \mathrm{N} / \mathrm{m}\end{array}$} & $\begin{array}{c}\mathrm{K} \\
\mathrm{kg} \mathrm{m}^{-1} \mathrm{~s}^{\mathrm{n}-2}\end{array}$ & \multicolumn{1}{c|}{$\mathrm{n}$} \\
\hline Water & 1000 & 0.0700 & 0.00083 & 1 \\
\hline n-Butanol & 1008 & 0.0350 & 0.00098 & 1 \\
\hline $80 \%$ Glycerol & 1180 & 0.0650 & 0.030 & 1 \\
\hline $60 \%$ Glycerol & 1155 & 0.0660 & 0.0185 & 1 \\
\hline $0.25 \%$ CMC & 1026 & 0.0730 & 0.0197 & 0.87 \\
\hline $0.6 \%$ CMC & 1020 & 0.0735 & 0.0308 & 0.86 \\
\hline $1.0 \%$ CMC & 1017 & 0.0740 & 0.0565 & 0.85 \\
\hline
\end{tabular}

Table 2. Properties of solids

\begin{tabular}{|l|l|l|l|}
\hline Particle description & Size, dp, $\mathrm{m}$ & Density, $\mathrm{kg} / \mathrm{m}^{3}$ & Particle sphericity \\
\hline Particle 1 & 0.001 & 2478 & 1 \\
\hline Particle 2 & 0.002 & 2478 & 1 \\
\hline Particle 3 & 0.003 & 2478 & 1 \\
\hline Particle 4 & 0.004 & 2478 & 1 \\
\hline Particle 5 & 0.005 & 2478 & 1 \\
\hline Particle 6 & 0.006 & 2478 & 1 \\
\hline Particle 7 & 0.01036 & 2478 & 1 \\
\hline Particle 8 & 0.0115 & 2456 & 0.33 \\
\hline Particle 9 & 0.01366 & 2083 & 0.58 \\
\hline
\end{tabular}




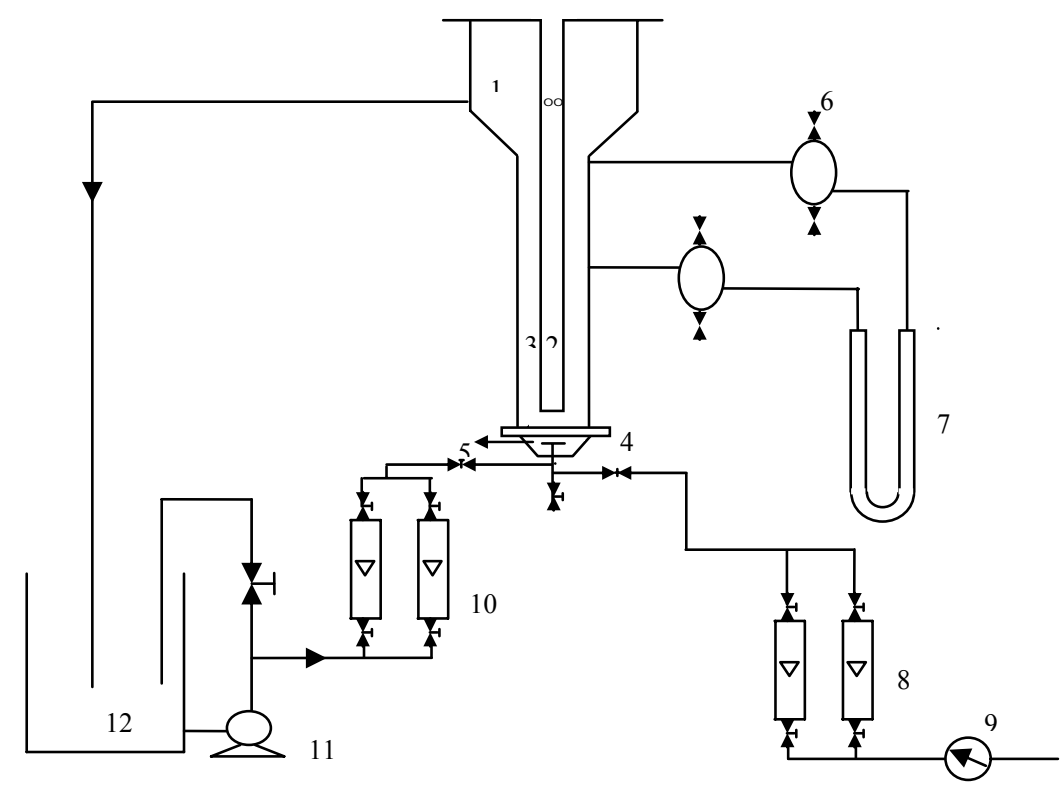
1. Degassing zone
2. Riser
3. Downcomer
4. Perforated plate
5. Sparger
6. Pressure taps

7. Manometer

8. Gas rotameter

9. Compressor

10. Liquid rotameter

11. Liquid pump

12. Liquid storage tank

Figure 1. Schematic Diagram of Internal Loop Airlift Fluidized Bed Reactor

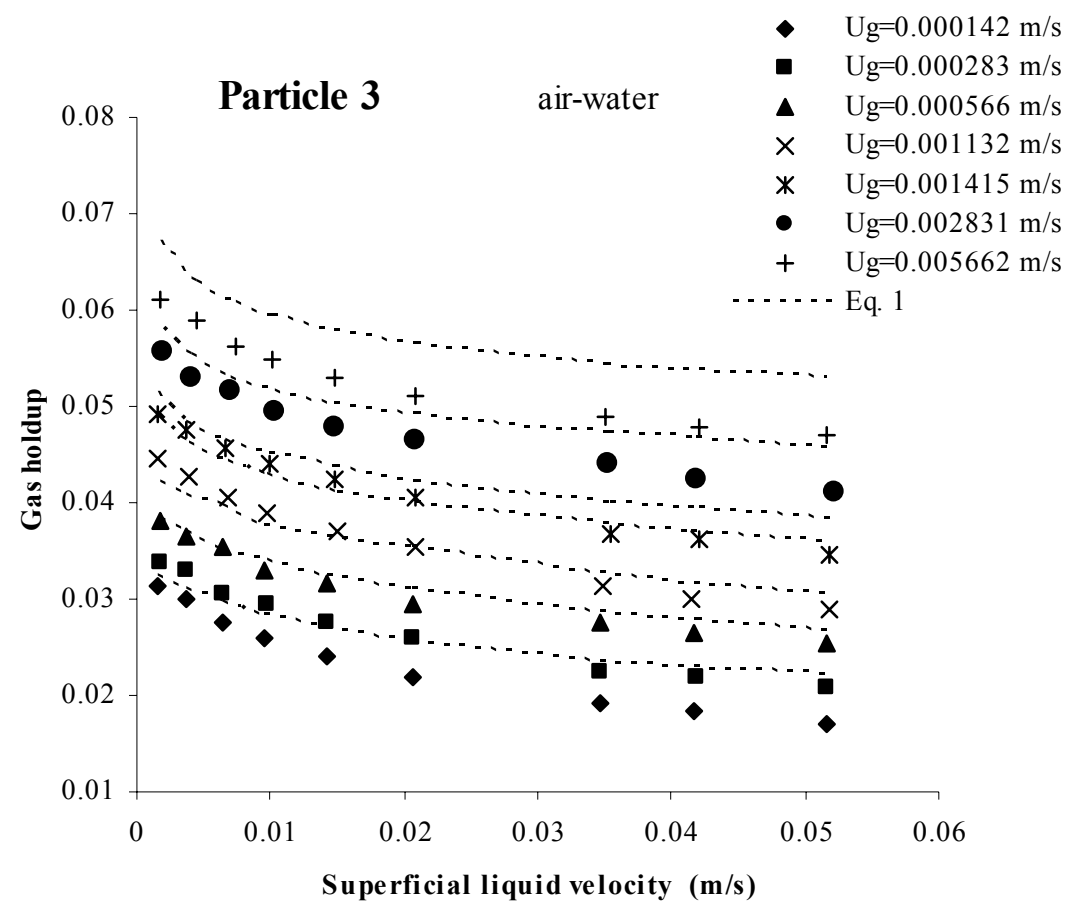

Figure 2. Effect of Phase Flow Rates on Gas Holdup 


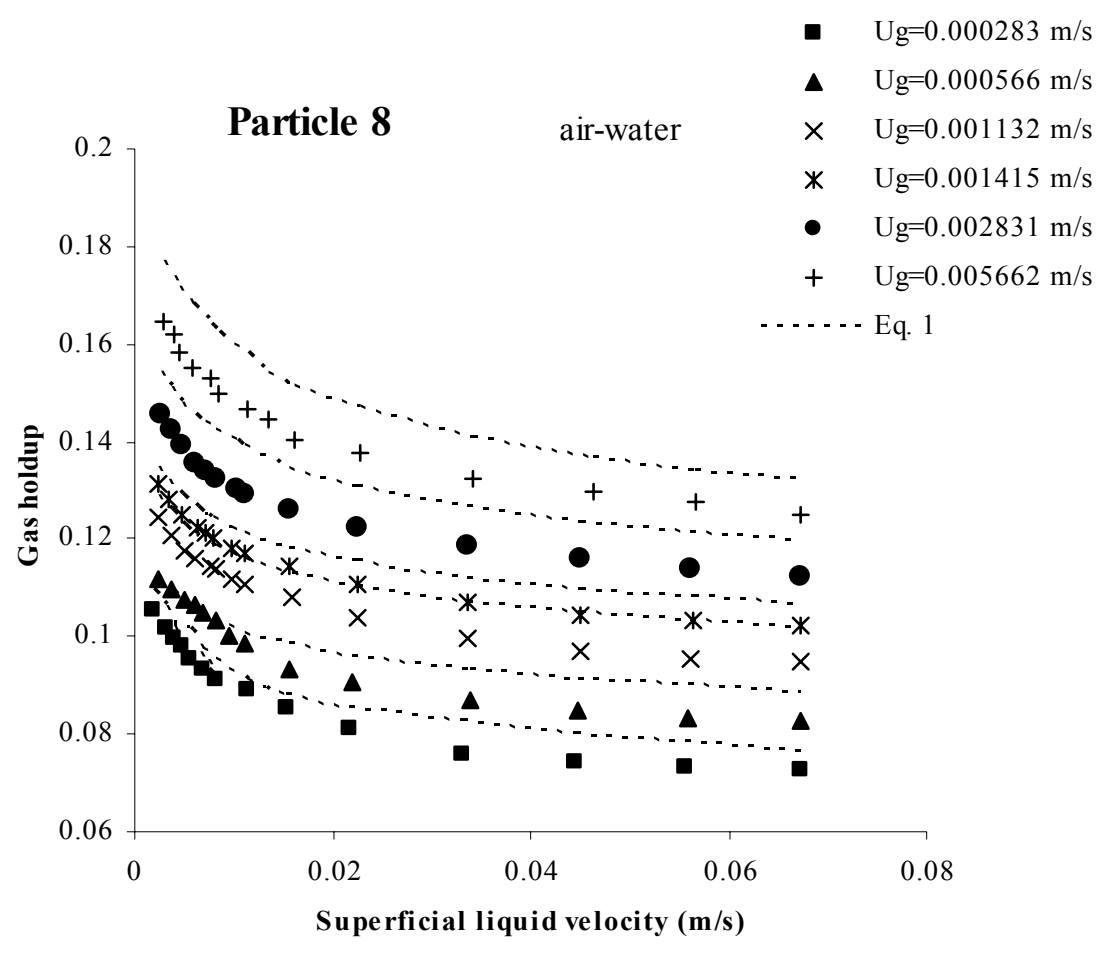

Figure 3. Effect of Phase Flow Rates on Gas Holdup

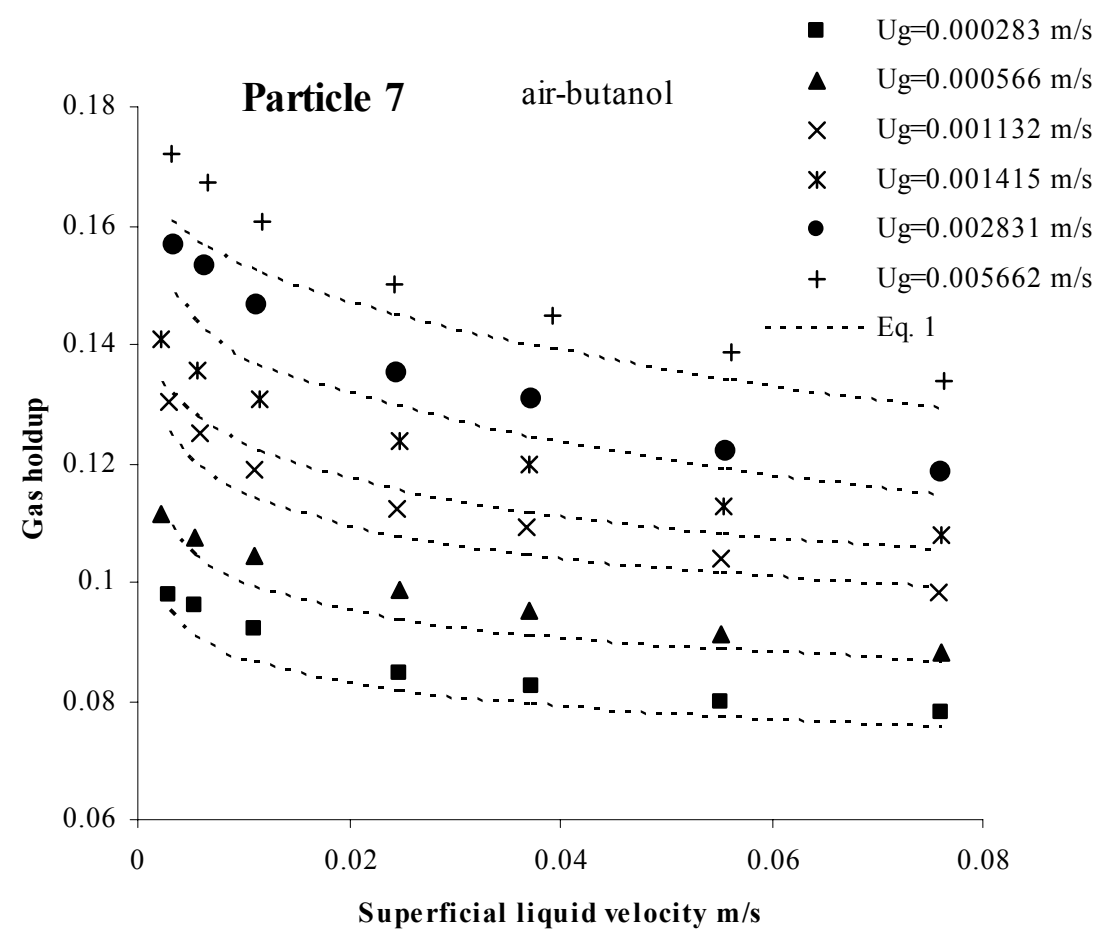

Figure 4. Effect of Phase Flow Rates on Gas Holdup for air-butanol System 


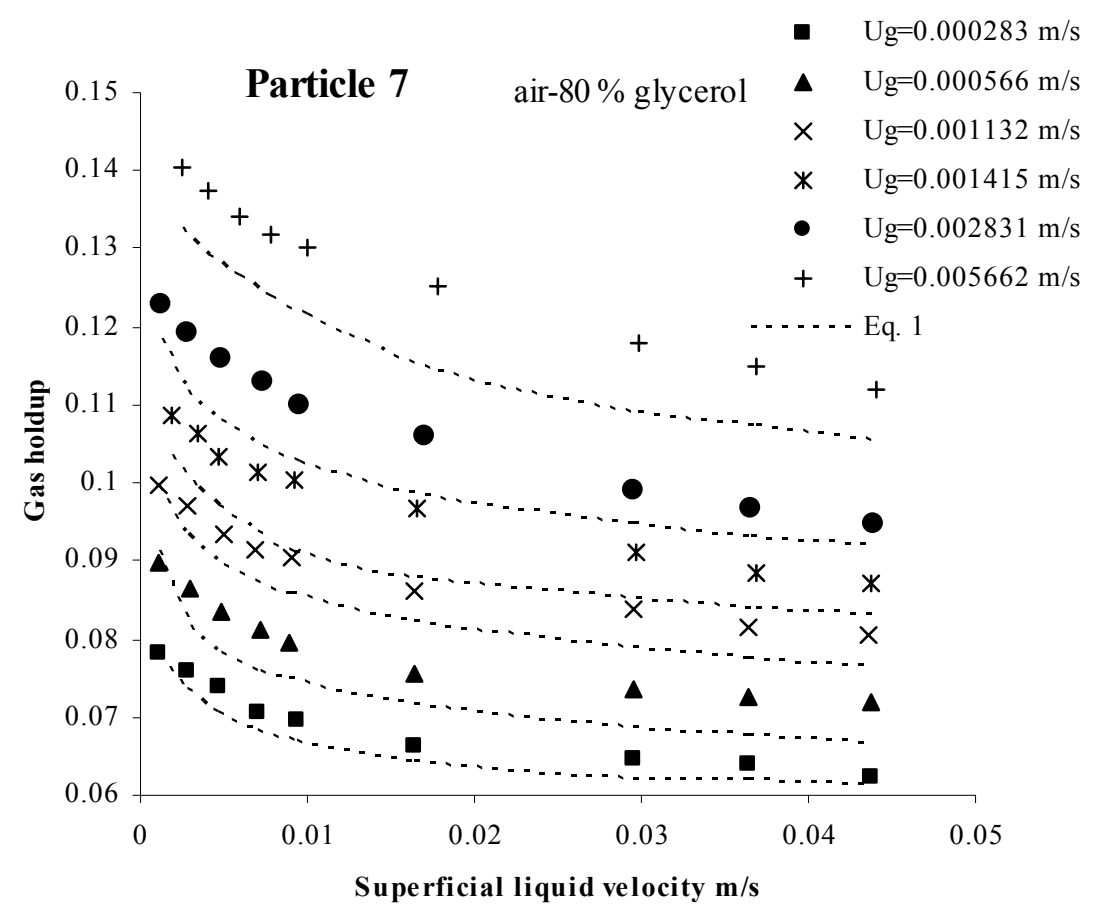

Figure 5. Effect of Phase Flow Rates on Gas Holdup for air- 80\% glycerol System

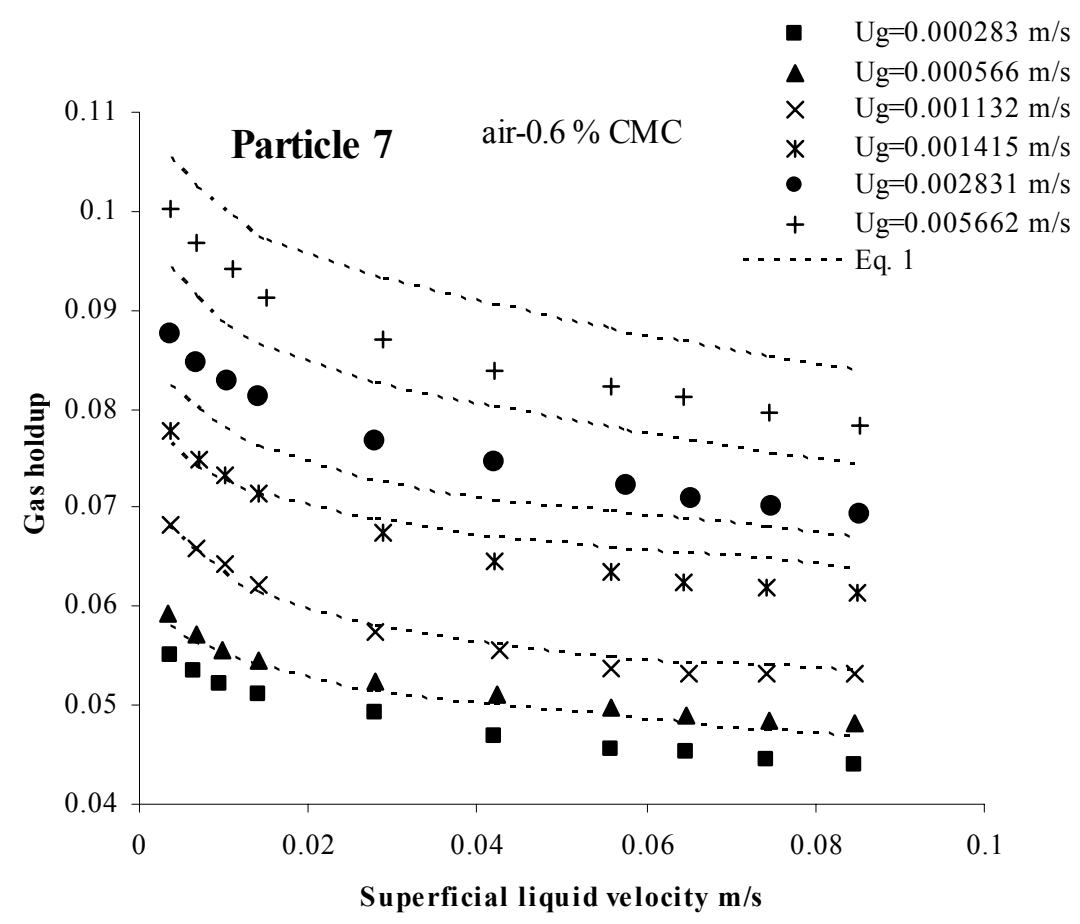

Figure 6. Effect of Phase Flow Rates on Gas Holdup for air- $0.6 \%$ CMC 


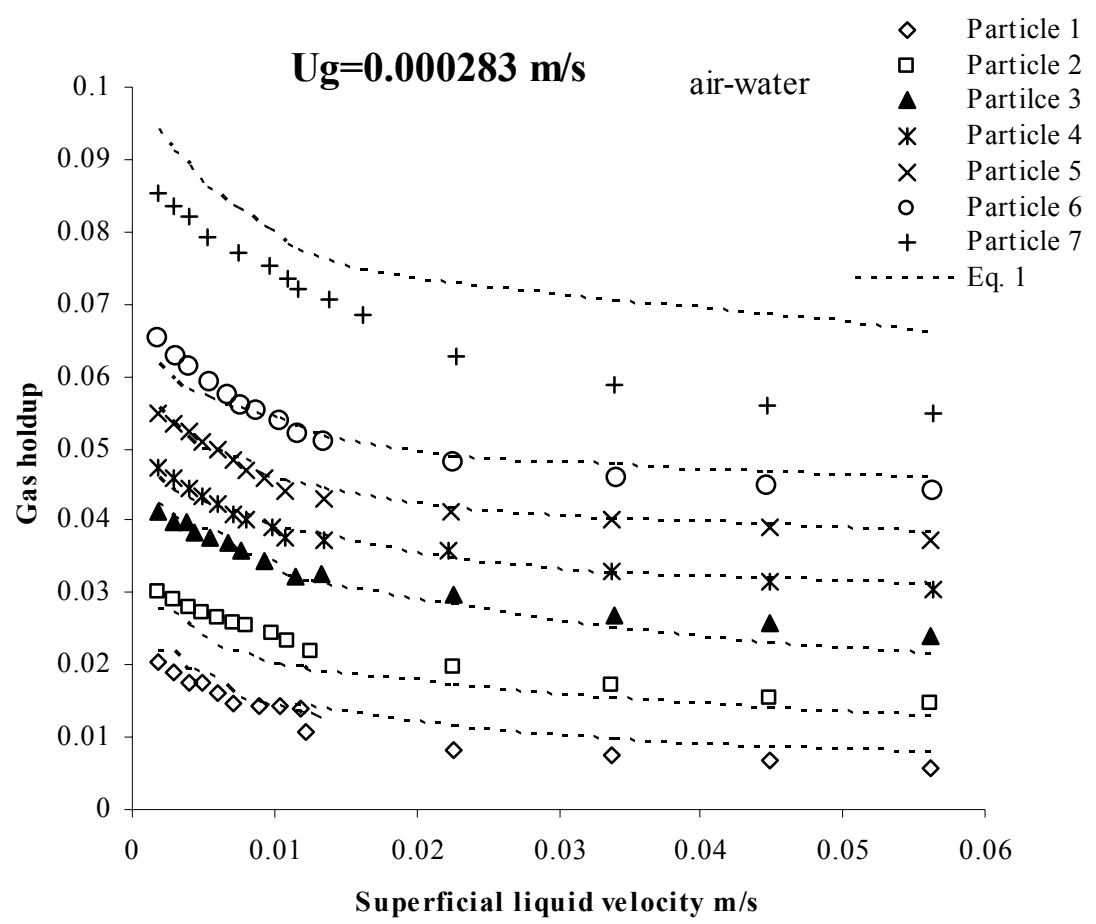

Figure 7. Effect of Particle Diameter on Gas Holdup

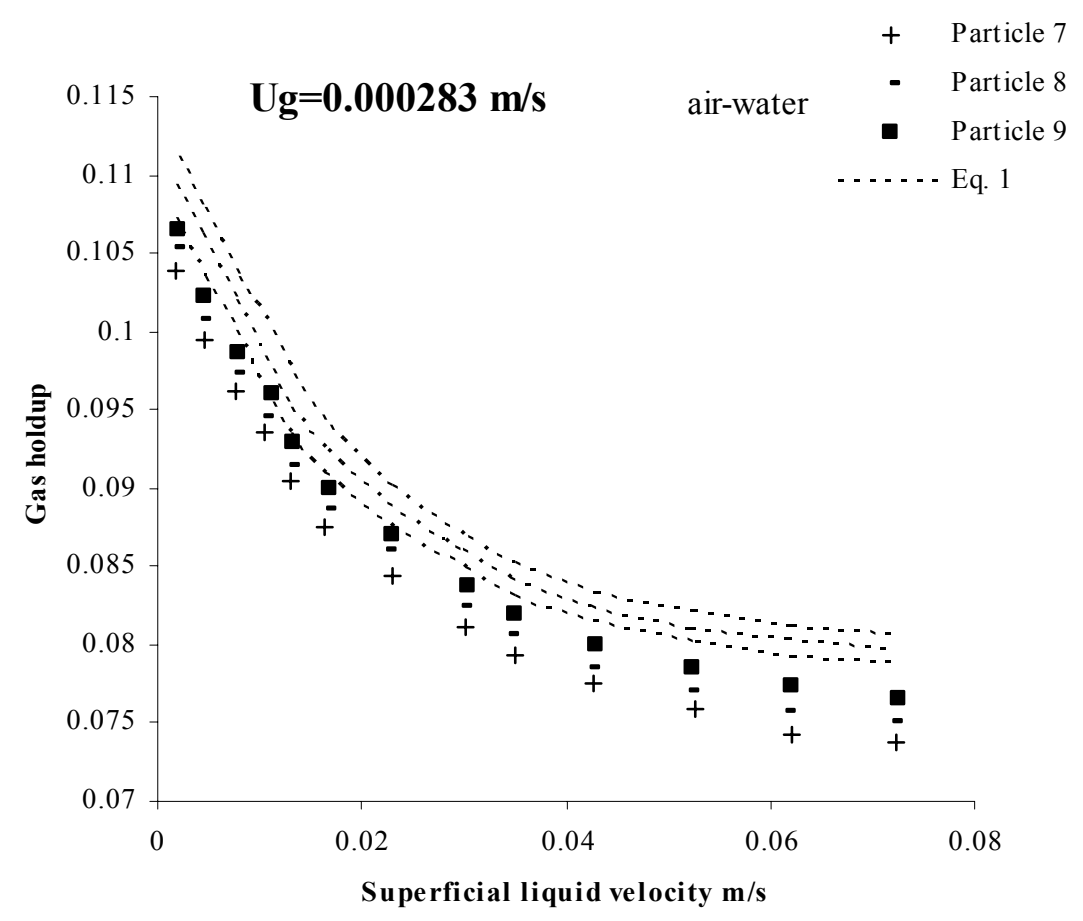

Figure 8. Effect of Particle Sphericity on Gas Holdup 


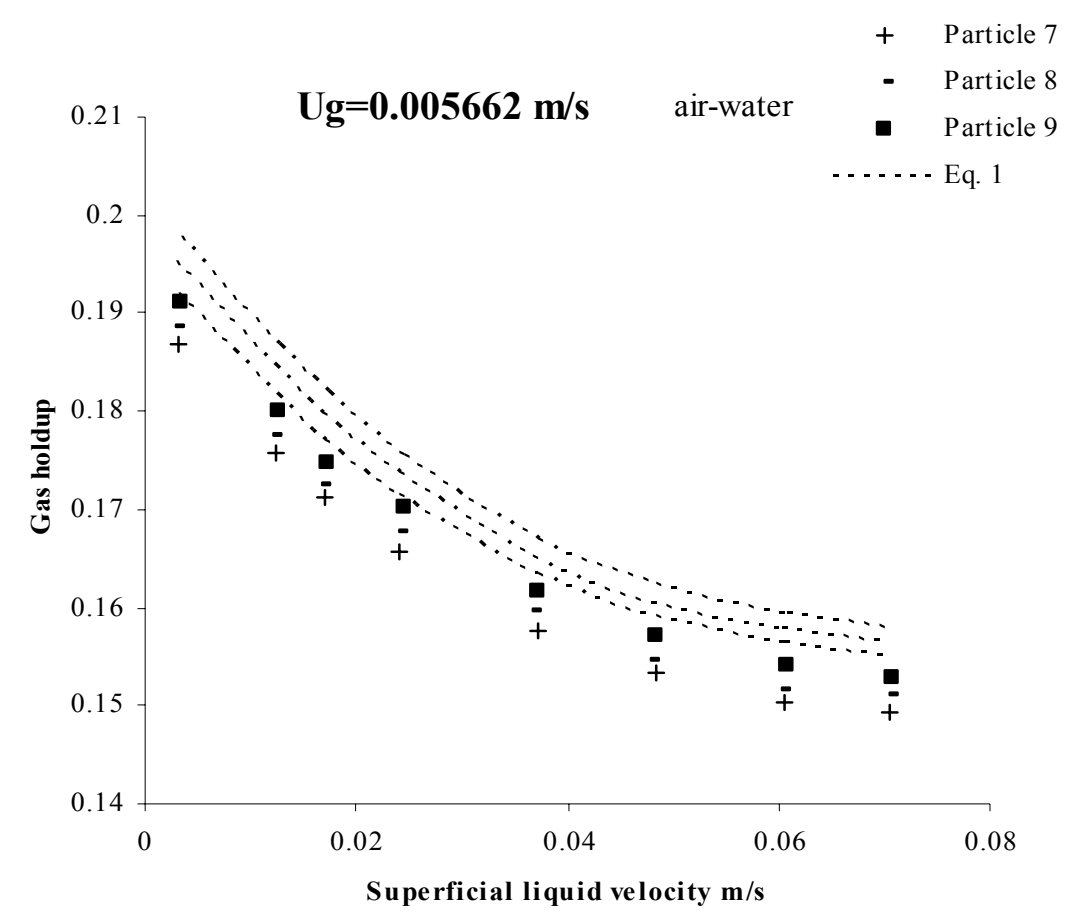

Figure 9. Effect of Particle Sphericity on Gas Holdup

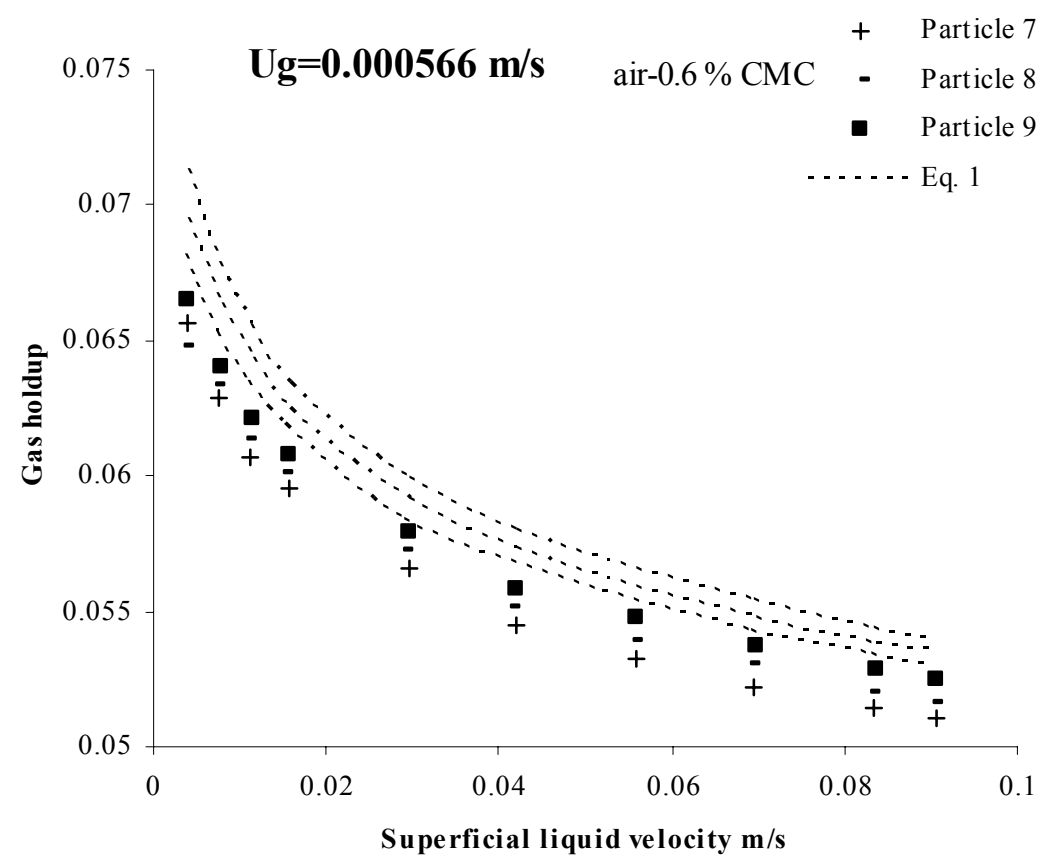

Figure 10. Effect of Particle Sphericity on Gas Holdup for air- $0.6 \%$ CMC 


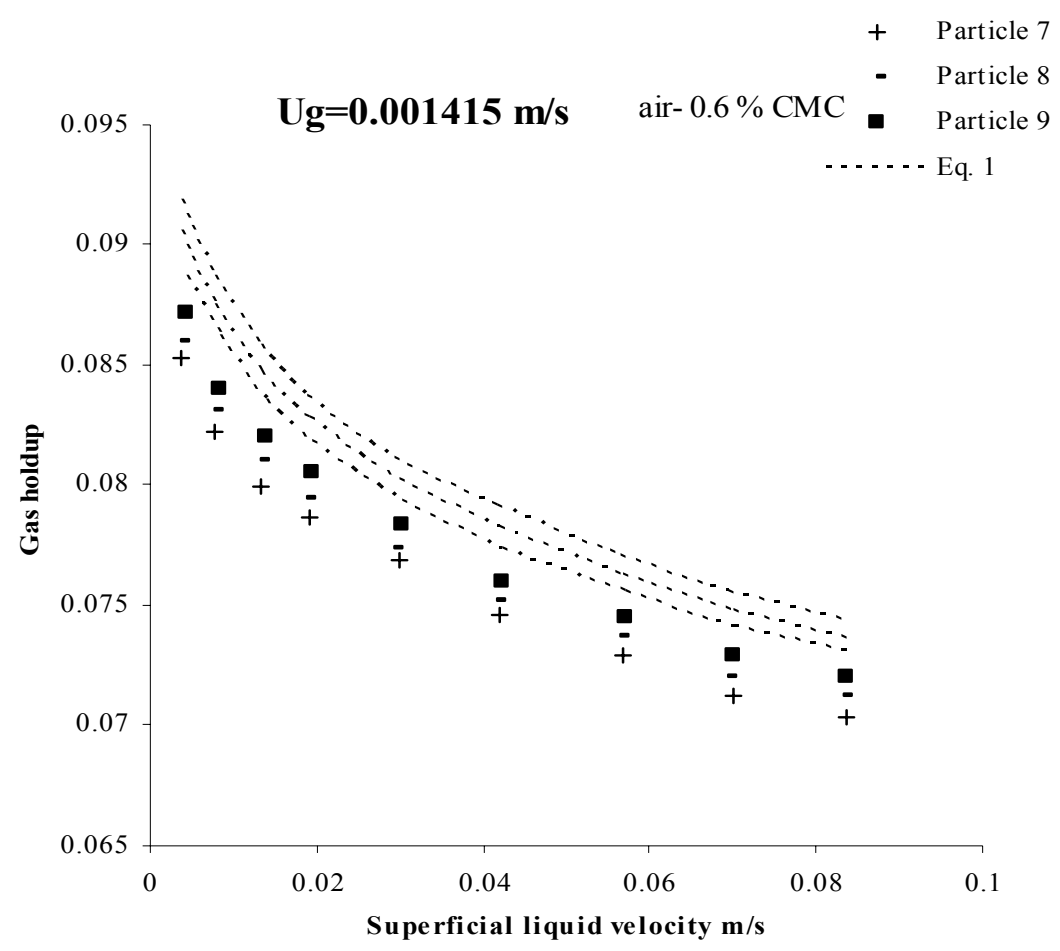

Figure 11. Effect of Particle Sphericity on Gas Holdup for air- $0.6 \%$ CMC

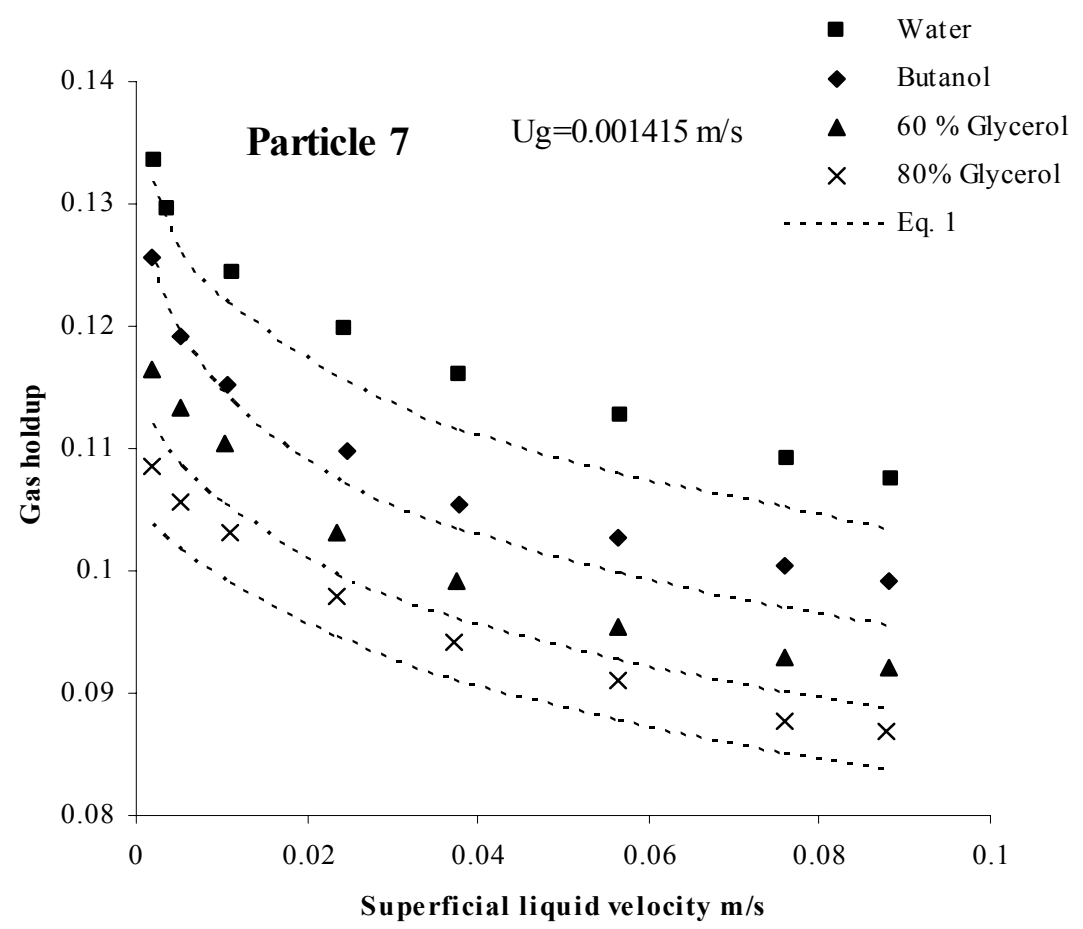

Figure 12. Effect of Physical Properties on Gas Holdup 


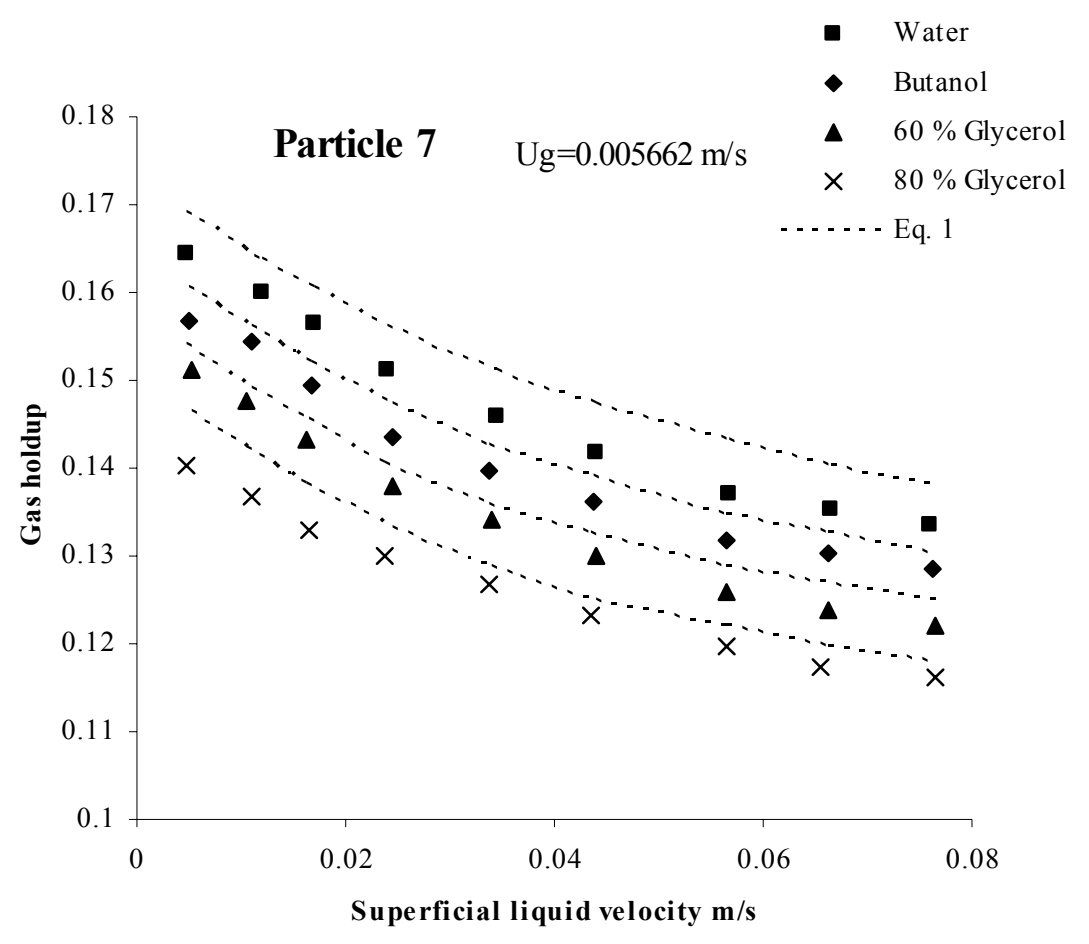

Figure 13. Effect of Physical Properties on Gas Holdup

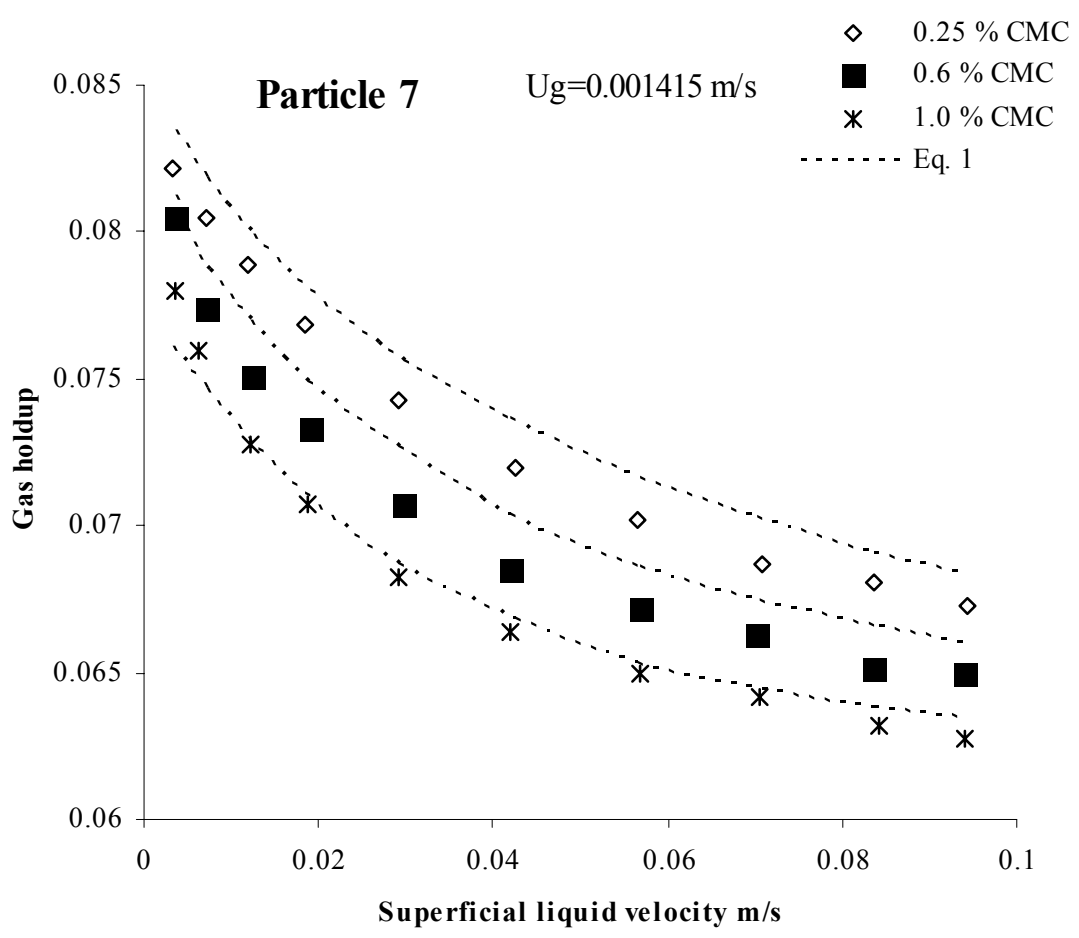

Figure 14. Effect of Rheological Properties on Gas Holdup 


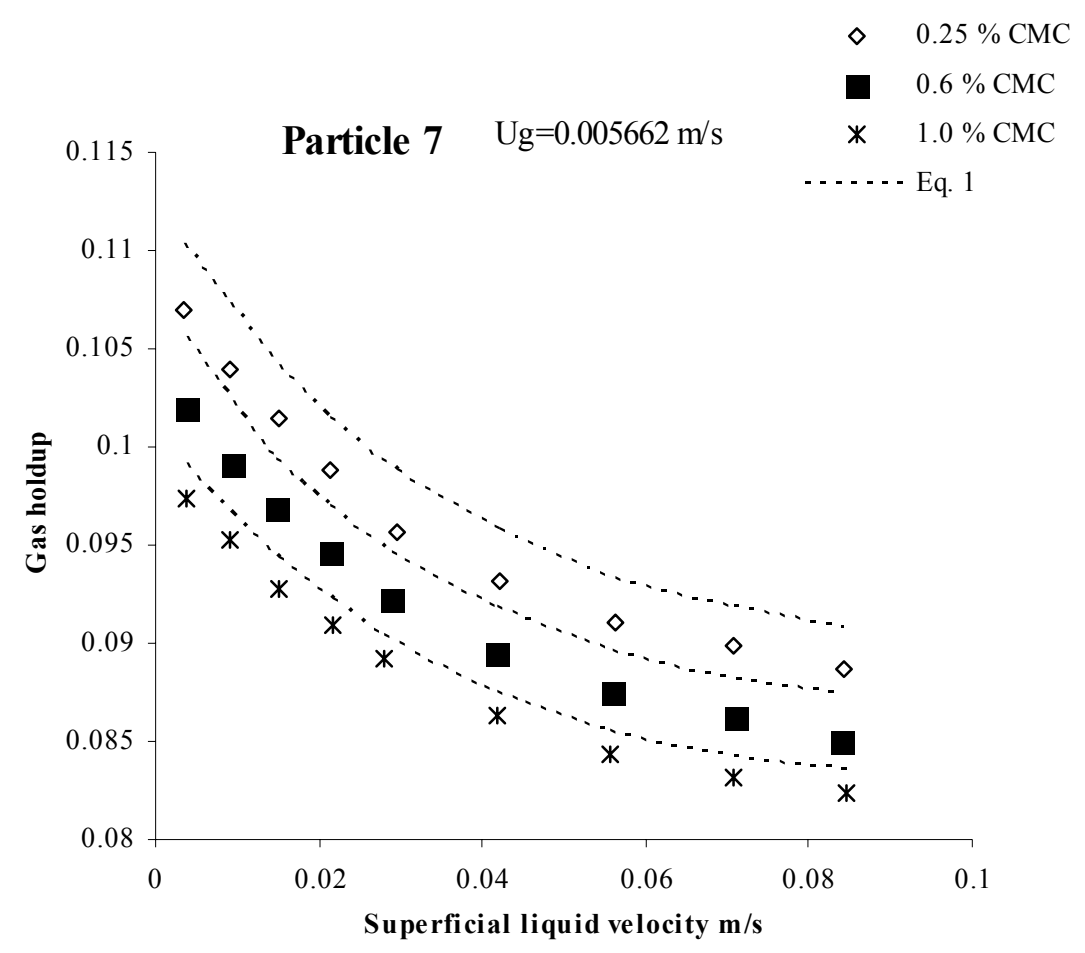

Figure 15. Effect of Rheological Properties on Gas Holdup

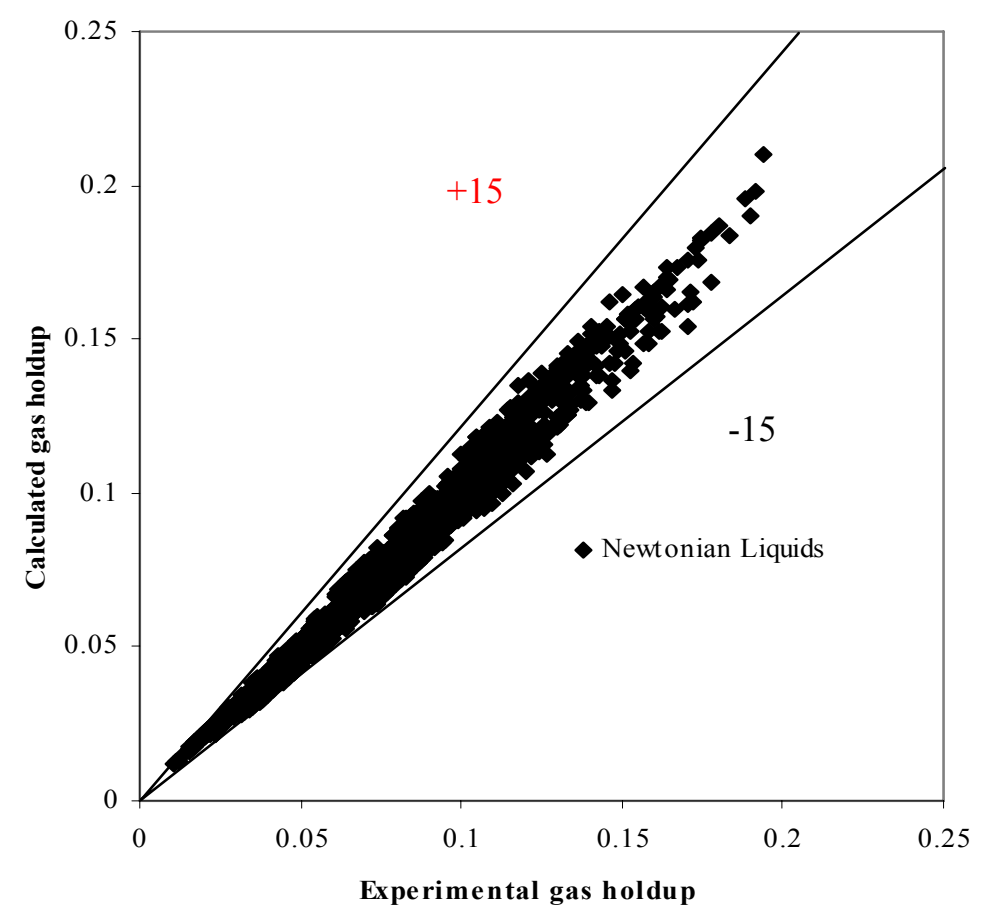

Figure 16. Comparison between the Experimental and Calculated Values of Gas Holdup for Newtonian Liquids 


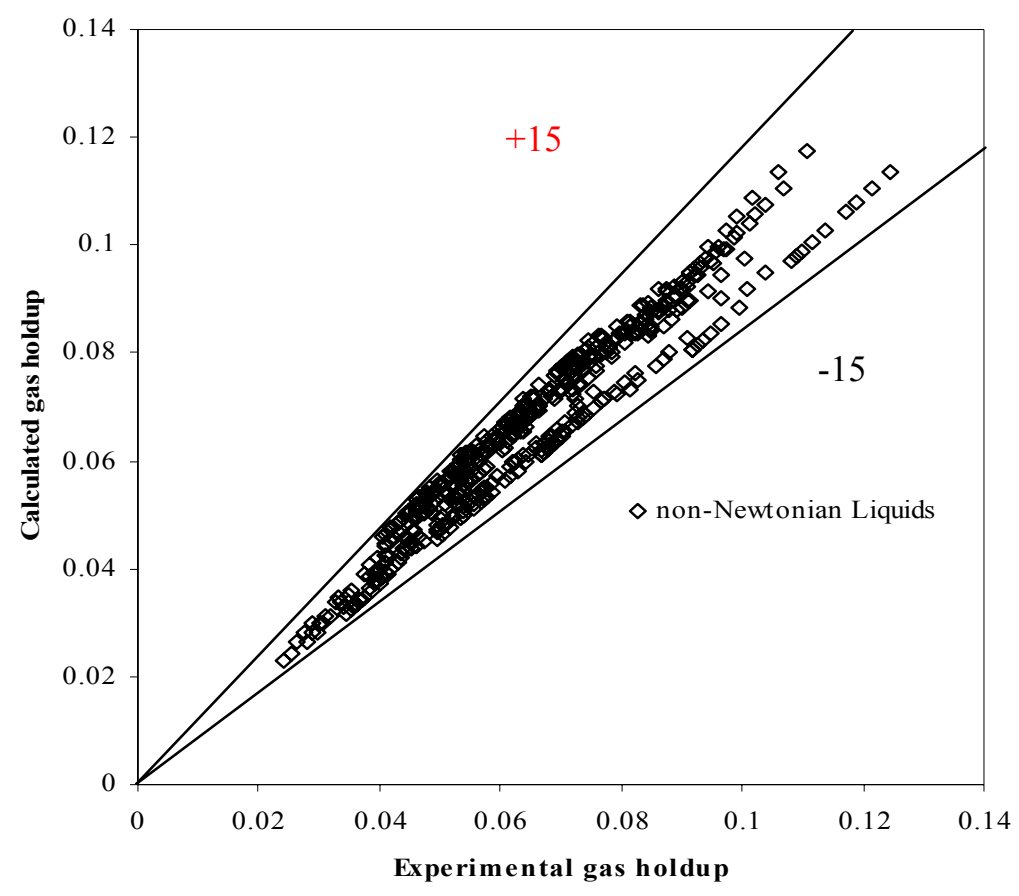

Figure 17. Comparison between the Experimental and Calculated Values of Gas Holdup for non-Newtonian Liquids 